Editorial

\title{
Beyond Plagiarism: Scientific Ethics and Its Other Aspects
}

\author{
Svetla Baykoucheva \\ STEM Library, University of Maryland, College Park, MD 20742, USA; sbaykouc@umd.edu; \\ Tel.: +1-301-405-9080
}

Received: 27 April 2018; Accepted: 7 May 2018; Published: 8 May 2018

The purpose of science is to advance human knowledge, cure diseases, and make life for people better. Does the current competitive environment in academia allow researchers to pursue such noble goals? The increase we see in the number of articles retracted by even reputable journals is quite alarming, and we need to have an honest discussion about why this is happening.

When talking about scientific ethics, we usually focus on plagiarism and scientific fraud. Scientific misconduct may be very subtle (like, not citing peer's articles), but sometimes it is more obvious (fabricating results). Scientific ethics, though, is much more than plagiarism and fabrication of data. As you will see, the authors of the articles included in this issue have looked at scientific ethics from a broader perspective.

In his opinion piece, Ádám Kun describes a culture of research in academia that is impact/ citations-obsessed - a culture of research, which creates a fertile soil for scientific misconduct to flourish. The author is concerned that "Something is wrong with science as there is an increasing amount of unreliable, manipulated and outright faked results appearing in the literature" [1]. He shows how the existing pay structure and assessment system influence researchers' motivation, goals, and behavior. He describes an academic environment that makes advancement (and even survival) of young researchers very difficult. Using analogies from evolutionary biology ("you get what you screen for"), he shows how "a competitive environment, in which achievement is measured by bibliometric numbers ... leads to a selection regime, in which there is a pressure to quickly amass as much bibliometric number/prestige as possible. It is in the self-interest of individuals to pursue quick ascension even if the way is paved with scientific fraud, misconduct, and unrepeatable results". Kun is very concerned that the existing academic climate may indoctrinate generations of future scientists with this kind of mentality.

Richard H. McCuen assesses the journal publication process from different perspectives. He discusses fundamental values relevant to scientific journal publication; stakeholders involved in professional journals; stages of the journal publication process where ethical dilemmas arise; and possible actions that could minimize unethical practices [2]. He describes the values and the responsibilities of different stakeholders in the publication process and recommends specific actions for preventing ethical problems and making the publication process more efficient.

If you are monitoring RetractionWatch [3], a Web site that reports articles retracted from scientific journals, you may have wondered who actually created the retraction notices. A retraction notice (RN) is an official document announcing the retraction of an article from a journal. Since the retraction of published research is often associated with scientific misconduct (which may have negative influence on the persons involved), the provenance of RNs is often obscure. According to Shaoxiong (Brian) $\mathrm{Xu}$ and Guangwei $\mathrm{Hu}$, such "ambiguity of authorship ... has serious ethical ramifications and creates methodological problems for research on RNs that requires clear authorship attribution" [4]. Their study identified some RN textual features that could be used "to disambiguate obscured authorship". The authors have studied RNs archived in the Web of Science for two disciplines: 
(1) Cell Biology and (2) Business, Finance, and Management. The results from this study show that there is a need for more explicit requirements about $\mathrm{RN}$ authorship and their enforcement.

In their commentary piece, Shahryar Sorooshian and Yasaman Parsia are very critical of the practices of some journals in processing manuscripts submitted for publication [5]. The authors present three cases of flawed practices in reviewing, editorial decisions, and communicating with the authors. The authors discuss how such mismanagement affects the motivation of authors to continue with the publication process of their articles.

During my years spent in the lab, I became an unwilling witness of incidents of scientific misconduct. More recently, in interviews with scientists [6,7], as well as in chapters of my book [8], I have tried to understand what makes people risk their careers and reputation by getting involved in scientific misconduct. The articles and opinion pieces included in this issue raise important questions about the current academic environment and scientific publishing that nourish such behavior and I hope they will contribute to our common understanding of the reasons for violations of scientific ethics.

Funding: This research received no external funding.

Conflicts of Interest: The author declares no conflict of interest.

\section{References}

1. Kun, Á. Publish and Who Should Perish: You or Science? Publications 2018, 6, 18. [CrossRef]

2. McCuen, R. Advancing Scientific Knowledge: Ethical Issues in the Journal Publication Process. Publications 2018, 6, 1. [CrossRef]

3. RetractionWatch. Available online: https:/ / retractionwatch.com/ (accessed on 26 April 2018).

4. Xu, S.; Hu, G. Retraction Notices: Who Authored Them? Publications 2018, 6, 2. [CrossRef]

5. Sorooshian, S.; Parsia, Y. Substandard Journal Management: Wastage of Authors' Motivation. Publications 2018, 6, 11. [CrossRef]

6. Baykoucheva, S. Political, cultural, and technological impacts on chemistry. An interview with Michael Gordin, Director of Graduate Studies of the Program in the History of Science, Princeton University. Chem. Inf. Bull. 2011, 63. Available online: http://www.acscinf.org/content/political-cultural-andtechnological-impacts-chemistry (accessed on 26 April 2018).

7. Baykoucheva, S. Interview with Eugene Garfield. Chem. Infor. Bull. 2006, 58, 7-9. Available online: http:/ / acscinf.org/content/interview-eugene-garfield (accessed on 26 April 2018).

8. Baykoucheva, S. Managing Scientific Information and Research Data; Chandos Publishing (an imprint of Elsevier): Oxford, UK, 2015.

(C) 2018 by the author. Licensee MDPI, Basel, Switzerland. This article is an open access article distributed under the terms and conditions of the Creative Commons Attribution (CC BY) license (http://creativecommons.org/licenses/by/4.0/). 